\title{
Curious case of a concave cap
}

Christopher James Manning, ${ }^{1}$ Robert Cooke, ${ }^{2}$ Abdul Bari ${ }^{2}$

${ }^{1}$ Trauma \& Orthopaedics, Wythenshawe Hospital, Manchester, UK ${ }^{2}$ Department of Orthopaedics, Tameside General Hospital, Ashton-under-Lyne, UK

Correspondence to Christopher James Manning, cmanning2@doctors.org.uk

Accepted 16 May 2019

\section{DESCRIPTION}

We present a striking image of an elderly woman's knee radiograph (figure 1), in particular, the size and shape of the patella. This particular patient was diagnosed with left knee osteoarthritis, primarily

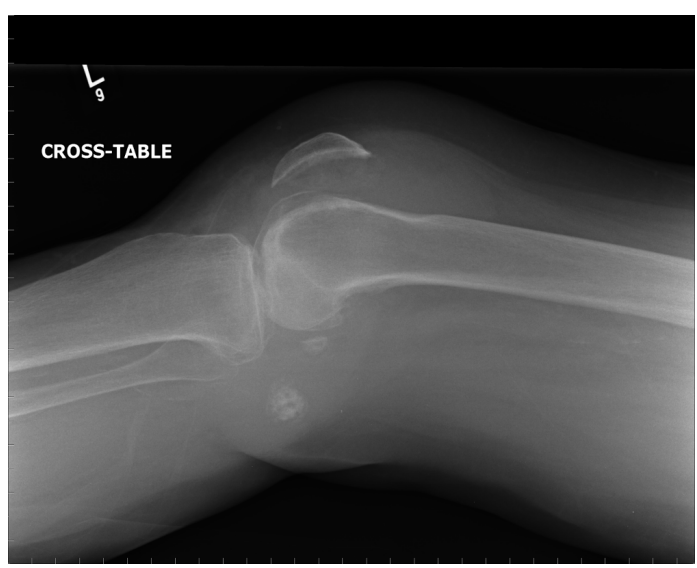

Figure 1 Lateral knee radiograph showing a flat (or convex) trochlea with a concave patella.

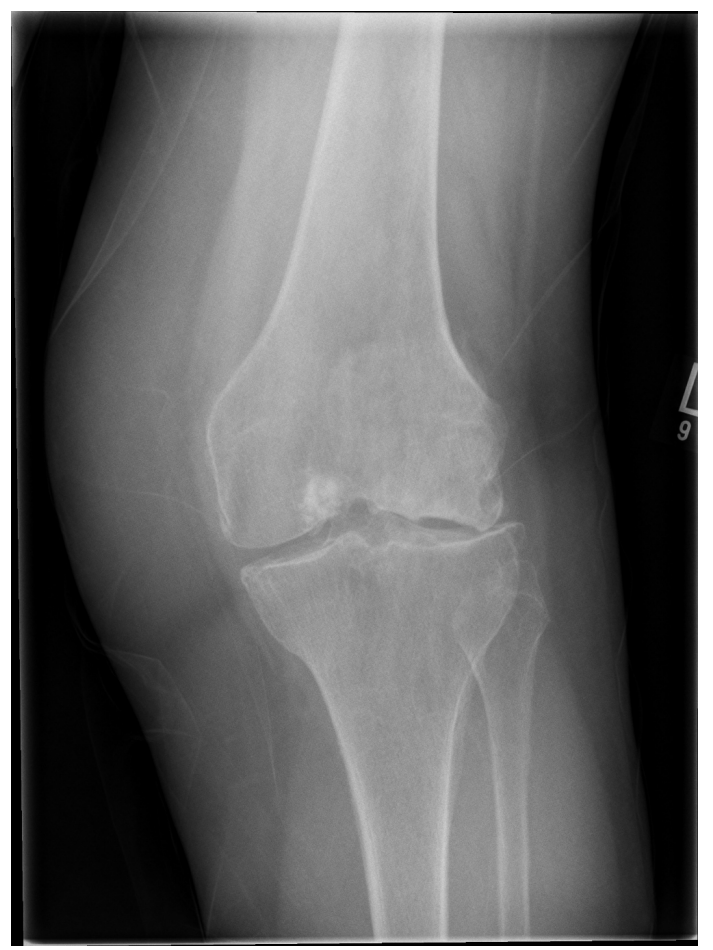

Figure 2 Anteroposterior knee radiograph showing lateral compartment osteoarthritis with slight valgus deformity. affecting the lateral compartment (figure 2); the patient had elected to undergo total knee replacement. However, the size and morphology of the patella were noted to be unusual. Intraoperatively, the depth of the patella measured only $10 \mathrm{~mm}$. This meant that the patella resurfacing was not undertaken as the patella lacked sufficient depth to allow resection of the joint surface and leave sufficient bone to accept the pegs of the resurfacing implant.

The patient's trochlea was dysplastic, and that has led to the patella conforming to the equivalent shape and becoming concave. Classification of trochlear morphology is well analysed and described in relation to patella instability by Lippacher et al (trochlea and patella). ${ }^{1}$ However, the corresponding patella morphology, or the effect of differing trochlea shapes on the patella, is not as well explored. Interestingly, this patient had never experienced any patella instability.

This case highlights the variation in anatomy relating to the trochlea and the patella, its relevance in relation to thorough assessment and planning prior to any surgical procedure, and how imperative it is to know the limitations of the equipment and prostheses that we use in medical practice.

\section{Learning points}

- There is considerable variation in anatomy relating to the trochlea and the patella.

- The importance of thorough assessment and planning prior to any surgical procedure is highlighted.

- It is imperative to know the limitations of the equipment and prostheses that we use in medical practice.

Contributors CJM: planning, design, writing of the article and literature review. RC: planning, writing of the article and discussion with the patient. $A B$ : planning, design, writing, editing and interpretation of images.

Funding The authors have not declared a specific grant for this research from any funding agency in the public, commercial or not-for-profit sectors.

Competing interests None declared.

Patient consent for publication Obtained.

Provenance and peer review Not commissioned; externally peer reviewed.

\section{REFERENCE}

1 Lippacher S, Dejour D, Elsharkawi M, et al. Observer agreement on the Dejour trochlear dysplasia classification: a comparison of true lateral radiographs and axial magnetic resonance images. Am J Sports Med 2012;40:837-43. 
Images in...

Copyright 2019 BMJ Publishing Group. All rights reserved. For permission to reuse any of this content visit https://www.bmj.com/company/products-services/rights-and-licensing/permissions/

BMJ Case Report Fellows may re-use this article for personal use and teaching without any further permission.

Become a Fellow of BMJ Case Reports today and you can:

- Submit as many cases as you like

- Enjoy fast sympathetic peer review and rapid publication of accepted articles

Access all the published articles

Re-use any of the published material for personal use and teaching without further permission

Customer Service

If you have any further queries about your subscription, please contact our customer services team on +44 (0) 2071111105 or via email at support@bmj.com.

Visit casereports.bmj.com for more articles like this and to become a Fellow 